\title{
Triggering of Programmed Erythrocyte Death by Alantolactone
}

\author{
Kousi Alzoubi ${ }^{1}$, Salvatrice Calabrò ${ }^{1,2}$, Jasmin Egler ${ }^{1}$, Caterina Faggio ${ }^{2}$ and Florian Lang ${ }^{1, *}$ \\ 1 Department of Physiology, University of Tübingen, Gmelinstr. 5, 72076 Tuebingen, Germany; \\ E-Mails: kossai.z@gmail.com (K.A.); salva24@inwind.it (S.C.); jasmin.egler@t-online.de (J.E.) \\ 2 Department of Biological and Environmental Sciences, University of Messina, \\ Viale Ferdinando Stagno d'Alcontres 31, 98166 S. Agata-Messina, Italy; E-Mail: cfaggio@unime.it \\ * Author to whom correspondence should be addressed; E-Mail: florian.lang@uni-tuebingen.de; \\ Tel.: +49-7071-29-72194; Fax: +49-7071-29-5618.
}

External Editor: Carmela Fimognari

Received: 13 October 2014; in revised form: 10 December 2014 / Accepted: 17 December 2014 / Published: 22 December 2014

\begin{abstract}
The sesquiterpene alantolactone counteracts malignancy, an effect at least in part due to stimulation of suicidal death or apoptosis of tumor cells. Signaling of alantolactone induced apoptosis involves altered gene expression and mitochondrial depolarization. Erythrocytes lack mitochondria and nuclei but may enter suicidal death or eryptosis, which is characterized by cell shrinkage and cell membrane scrambling with phosphatidylserine exposure at the erythrocyte surface. Cellular mechanisms involved in triggering of eryptosis include increase of cytosolic $\mathrm{Ca}^{2+}$-activity $\left(\left[\mathrm{Ca}^{2+}\right]_{i}\right)$ and oxidative stress. The present study explored, whether alantolactone stimulates eryptosis. To this end, erythrocyte volume was estimated from forward scatter, phosphatidylserine-exposure at the erythrocyte surface from FITC-annexin-V-binding, $\left[\mathrm{Ca}^{2+}\right]_{i}$ from Fluo3-fluorescence, ceramide abundance from binding of fluorescent antibodies, and oxidative stress from 2',7'-dichlorodihydrofluorescein-diacetate (DCFDA) fluorescence. As a result, a $48 \mathrm{~h}$ exposure of human erythrocytes to alantolactone $(\geq 20 \mu \mathrm{M})$ significantly decreased erythrocyte forward scatter and increased the percentage of annexin-V-binding cells. Alantolactone significantly increased Fluo3 fluorescence $(60 \mu \mathrm{M})$, ceramide abundance $(60 \mu \mathrm{M})$ and DCFDA fluorescence $(\geq 40 \mu \mathrm{M})$. The effect of alantolactone $(60 \mu \mathrm{M})$ on annexin-V-binding was not significantly modified by removal of extracellular $\mathrm{Ca}^{2+}$. In conclusion, alantolactone stimulates suicidal erythrocyte death or eryptosis, an effect paralleled by increase of $\left[\mathrm{Ca}^{2+}\right] i$, ceramide abundance and oxidative stress.
\end{abstract}


Keywords: phosphatidylserine; alantolactone; ceramide; oxidative stress; cell volume; eryptosis

\section{Introduction}

Alantolactone, a sesquiterpene isolated from several medicinal plants [1], counteracts inflammation, infection and malignancy [1]. Its anticancer efficacy is attributed to its ability to induce apoptosis of tumor cells [1]. Alantolactone triggers apoptosis of a variety of cells [2-11]. Cellular mechanisms involved in the stimulation of apoptosis by alantolactone include disruption of mitochondrial membrane potential $[3,6,8,11]$, induction of oxidative stress [3,4,8,11], interference with gene expression $[3,4,6,7,9,10]$, increased $\mathrm{Bax} / \mathrm{Bcl}-2$ ratio $[3,7,10]$ and activation of caspases $[3,6-8,10]$.

Erythrocytes lack mitochondria and nuclei and are thus resistant to triggers of suicidal death effective by mitochondrial depolarization or altered gene expression [12]. Nevertheless, erythrocytes may undergo apoptosis-like suicidal death or eryptosis, which is characterized by cell shrinkage and break down of cell membrane phospholipid asymmetry with translocation of phosphatidylserine to the cell surface [12]. Stimulators of eryptosis include increase of cytosolic $\mathrm{Ca}^{2+}$ concentration $\left(\left[\mathrm{Ca}^{2+}\right] \mathrm{i}\right)$, which activates $\mathrm{Ca}^{2+}$-sensitive $\mathrm{K}^{+}$channels with subsequent $\mathrm{K}^{+}$exit, hyperpolarization, $\mathrm{Cl}^{-}$exit and thus cell shrinkage due to cellular loss of $\mathrm{KCl}$ with water [13]. Increase of $\left[\mathrm{Ca}^{2+}\right]$ i further leads to translocation of phosphatidylserine to the erythrocyte surface [12]. Cellular mechanisms triggering eryptosis further include ceramide [14], oxidative stress [15], activated caspases [16-20] decreased activities of AMP activated kinase AMPK [21], cGMP-dependent protein kinase [17], PAK2 kinase [22], sorafenib sensitive kinases [23] and sunifinib sensitive kinases [24], or excessive activities of casein kinase $1 \alpha[25,26]$, Janus-activated kinase JAK3 [27], protein kinase C [28], and p38 kinase [29].

Eryptosis has been extensively studied in both human and murine erythrocytes [12]. The involved mechanisms are similar but not necessarily identical [12]. Eryptosis is stimulated by a wide variety of chemicals [14,23,24,30-65] and excessive eryptosis is observed in several clinical conditions, including sepsis, fever, malaria, sickle cell disease, thalassemia, Wilson's disease, iron deficiency, hepatic failure, malignancy, metabolic syndrome, diabetes, dehydration, renal insufficiency, hemolytic uremic syndrome, hyperphosphatemia and phosphate depletion [12,66,67].

The present study explored, whether eryptosis is stimulated by alantolactone. To this end, human erythrocytes drawn from healthy volunteers were exposed to alantolactone and cell volume, phosphatidylserine abundance at the cell surface, $\left[\mathrm{Ca}^{2+}\right]$ i and reactive oxygen species (ROS) determined.

\section{Results and Discussion}

In order to test whether the sesquiterpene alantolactone triggers eryptosis, the suicidal erythrocyte death, human erythrocytes were exposed for $48 \mathrm{~h}$ to Ringer solution without or with alantolactone $(10-60 \mu \mathrm{M})$ and cell volume as well as phosphatidylserine translocation to the erythrocyte surface were determined.

Forward scatter was determined utilizing flow cytometry in order to estimate alterations of cell volume. As shown in Figure 1, a 48 h exposure to alantolactone-containing Ringer was followed by a decrease of forward scatter, an effect reaching statistical significance at $20 \mu \mathrm{M}$ alantolactone concentration. 
Figure 1. Effect of alantolactone on erythrocyte forward scatter. (A) Original histogram of forward scatter of erythrocytes following exposure for $48 \mathrm{~h}$ to Ringer solution without (grey area) and with (black line) presence of $60 \mu \mathrm{M}$ alantolactone; (B) Arithmetic means \pm SEM $(n=15)$ of the normalized erythrocyte forward scatter (FSC) following incubation for $48 \mathrm{~h}$ to Ringer solution without (white bar) or with (black bars) alantolactone $(10-60 \mu \mathrm{M})$. For comparison, the effect of $1 \mu \mathrm{L}$ DMSO/mL Ringer is shown (grey bar). * $(p<0.05), * * *(p<0.001)$ indicates significant difference from the absence of alantolactone (ANOVA); (C) Arithmetic means $\pm \operatorname{SEM}(n=4)$ of the normalized erythrocyte forward scatter (FSC) following incubation for $48 \mathrm{~h}$ to Ringer solution without alantolactone (white bar), or following $48 \mathrm{~h}$ treatment with $60 \mu \mathrm{M}$ alantolactone (black bar) or following $1 \mathrm{~h}$ treatment with $1 \mu \mathrm{M}$ ionomycin (grey bar). $* * *(p<0.001)$ indicates significant difference from the absence of treatment (ANOVA).
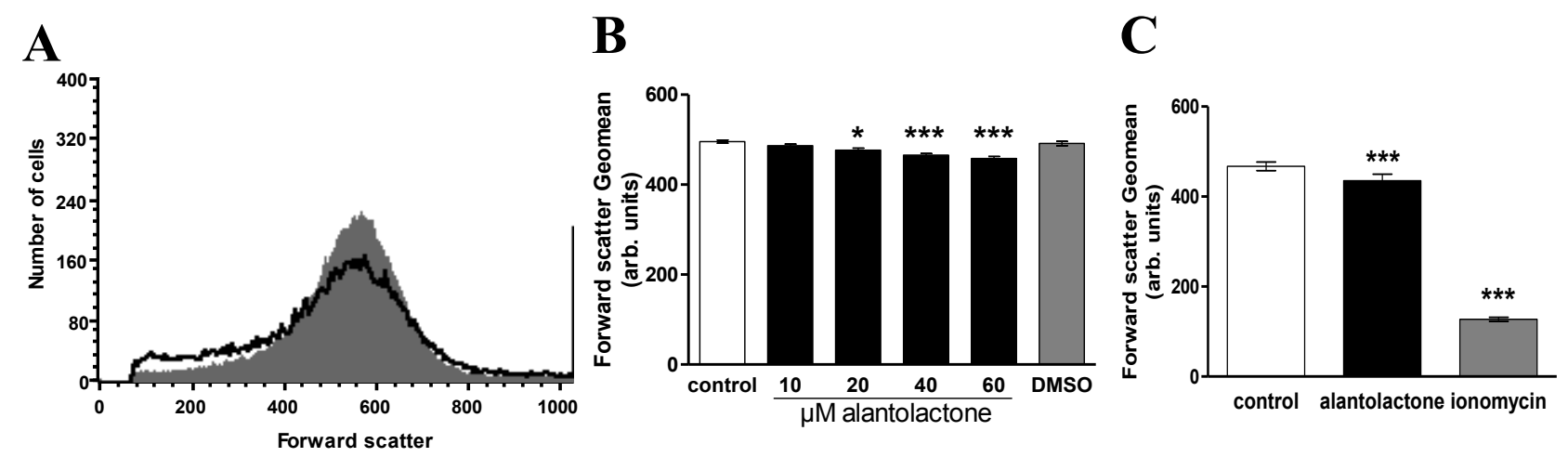

Phosphatidylserine translocation to the erythrocyte surface was quantified from binding of FITC-labelled annexin- $\mathrm{V}$ as determined in flow cytometry. As shown in Figure 2, a $48 \mathrm{~h}$ exposure to alantolactone was followed by an increase of the percentage of erythrocytes binding FITC-labelled annexin- $\mathrm{V}$, an effect reaching statistical significance at $20 \mu \mathrm{M}$ alantolactone concentration.

Hemolysis was estimated by determination of hemoglobin in the supernatant. As shown in Figure $2 \mathrm{~F}$, alantolactone tended to slightly increase the percentage of hemolysed erythrocytes, an effect, however, not reaching statistical significance.

Both, cell shrinkage and phosphatidylserine translocation to the cell surface could have resulted from an increase of cytosolic $\mathrm{Ca}^{2+}$ activity $\left(\left[\mathrm{Ca}^{2+}\right] \mathrm{i}\right)$. Thus, additional experiments explored the effect of alantolactone on $\left[\mathrm{Ca}^{2+}\right]$. Following a $48 \mathrm{~h}$ incubation in Ringer solution without or with alantolactone $(10-60 \mu \mathrm{M})$, the erythrocytes were loaded with Fluo3-AM and the Fluo3 fluorescence determined by flow cytometry. As shown in Figure 3, exposure of the erythrocytes to alantolactone was followed by an increase of Fluo3 fluorescence, an effect reaching statistical significance at $60 \mu \mathrm{M}$ alantolactone concentration. 
Figure 2. Effect of alantolactone on phosphatidylserine exposure. (A) Original histogram of annexin-V-binding erythrocytes following exposure for $48 \mathrm{~h}$ to Ringer solution without (grey area) and with (black line) presence of $60 \mu \mathrm{M}$ alantolactone; (B) Arithmetic means \pm SEM $(n=15)$ of erythrocyte annexin-V-binding following incubation for $48 \mathrm{~h}$ to Ringer solution without (white bar) or with (black bars) presence of alantolactone (10-60 $\mu \mathrm{M})$. For comparison, the effect of $1 \mu \mathrm{L} \mathrm{DMSO} / \mathrm{mL}$ Ringer is shown (grey bar). * $(p<0.05)$, $* * *(p<0.001)$ indicate significant difference from the absence of alantolactone (ANOVA); (C) Original dot plots of forward scatter vs annexin-V-FITC binding of erythrocytes following exposure for $48 \mathrm{~h}$ to Ringer solution without (left) and with (right) presence of $60 \mu \mathrm{M}$ alantolactone; (D) Arithmetic means $\pm \operatorname{SEM}(n=4)$ of the erythrocyte annexin $\mathrm{V}$ binding following incubation for $48 \mathrm{~h}$ to Ringer solution without treatment (white bar), following a $48 \mathrm{~h}$ treatment with $60 \mu \mathrm{M}$ alantolactone (black bar) or following a $1 \mathrm{~h}$ treatment with $1 \mu \mathrm{M}$ ionomycin (grey bar). $* * *(p<0.001)$ indicates significant difference from the absence of treatment (ANOVA); (E) Arithmetic means $\pm \operatorname{SEM}(n=4)$ of the percentage annexin $\mathrm{V}$ binding erythrocytes as a function of exposure time to Ringer without (open circles) or with (closed circles) alantolactone $(60 \mu \mathrm{M}) . * *(p<0.01)$, $* * *(p<0.001)$ indicate significant differences from absence of alantolactone (ANOVA); (F) Arithmetic means $\pm \operatorname{SEM}(n=4)$ of percentage of hemolysis as a function of exposure time to Ringer without (open circles) or with (closed circles) alantolactone $(60 \mu \mathrm{M})$.

A

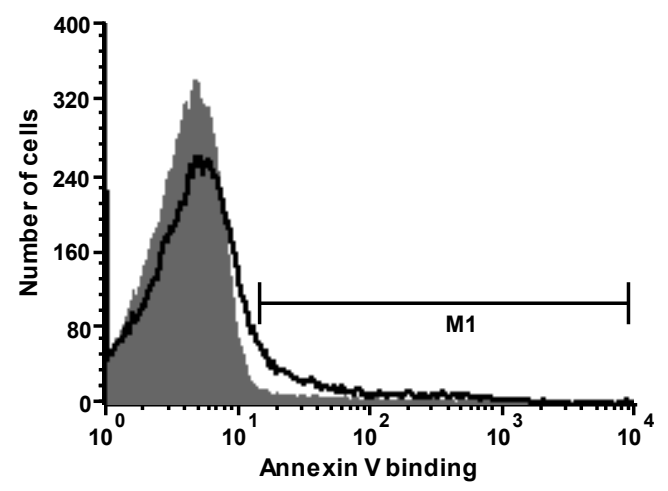

B

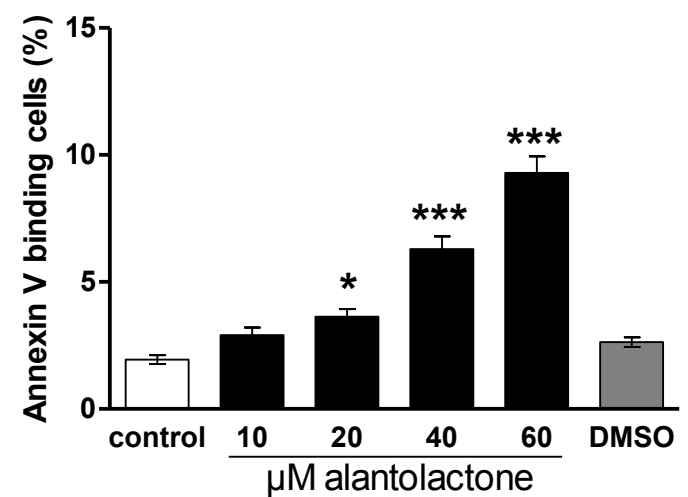

C

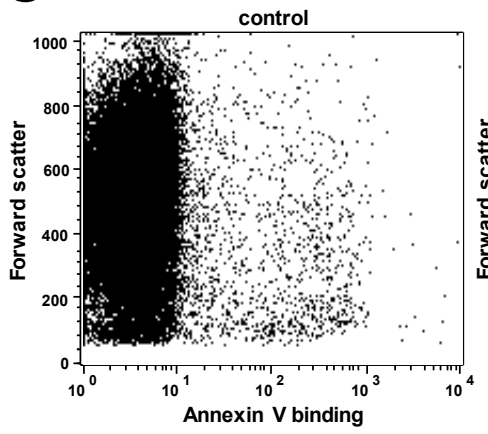

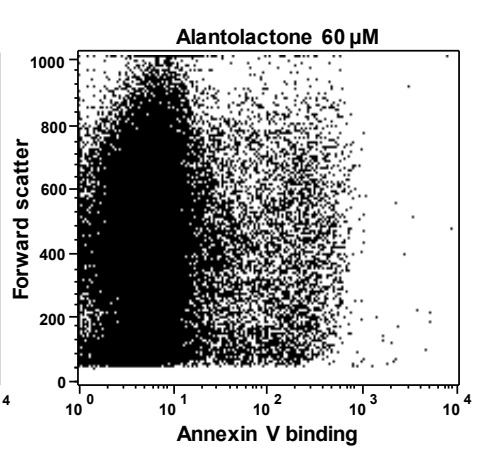

D

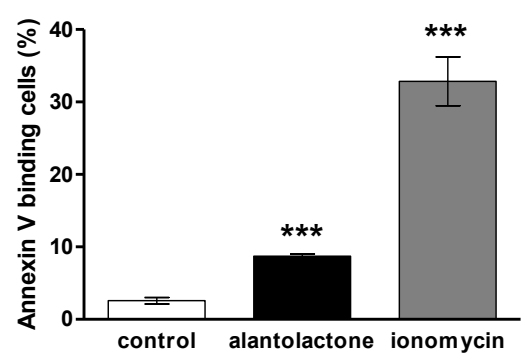


Figure 2. Cont.
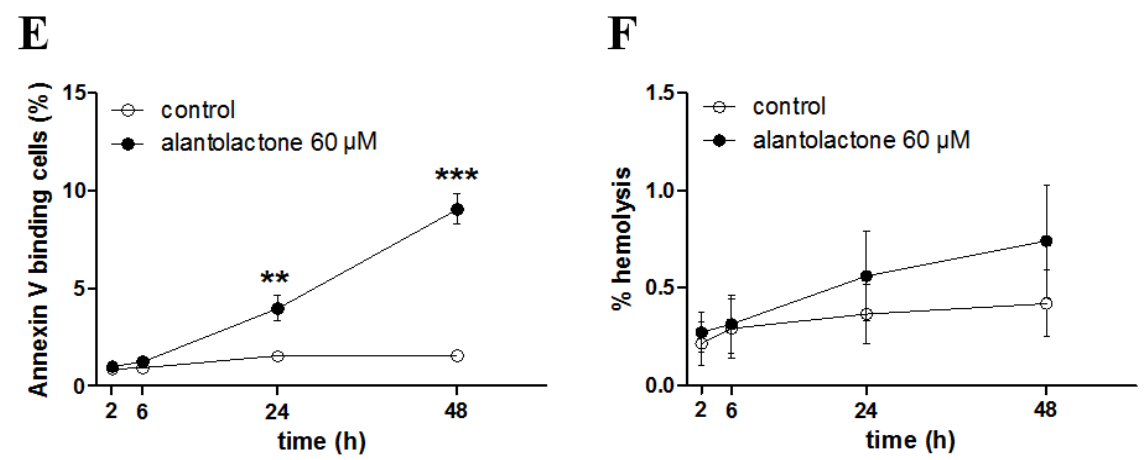

Figure 3. Effect of alantolactone on Fluo3 fluorescence. (A) Original histogram of Fluo3-fluorescence following exposure for $48 \mathrm{~h}$ to Ringer solution without (grey area) and with (black line) presence of $60 \mu \mathrm{M}$ alantolactone; (B) Arithmetic means $\pm \operatorname{SEM}(n=15)$ of erythrocyte Fluo3-fluorescence following incubation for $48 \mathrm{~h}$ to Ringer solution without (white bar) or with (black bars) presence of alantolactone $(10-60 \mu \mathrm{M})$. For comparison, the effect of $1 \mu \mathrm{L} \mathrm{DMSO} / \mathrm{mL}$ Ringer is shown (grey bar). ** $(p<0.01)$ indicate significant difference from the absence of alantolactone (ANOVA); (C) Original dot plots of forward scatter vs fluo3 fluorescence of erythrocytes following exposure for $48 \mathrm{~h}$ to Ringer solution without (left) and with (right) presence of $60 \mu \mathrm{M}$ alantolactone; (D) Arithmetic means $\pm \operatorname{SEM}(n=4)$ of the erythrocyte Fluo-3 fluorescence following incubation for $48 \mathrm{~h}$ to Ringer solution without treatment (white bar), following a $48 \mathrm{~h}$ treatment with $60 \mu \mathrm{M}$ alantolactone (black bars) or following $1 \mathrm{~h}$ treatment with $1 \mu \mathrm{M}$ ionomycin (grey bar). $*(p<0.05), * *(p<0.01)$ indicates significant difference from the absence of alantolactone (ANOVA).

A

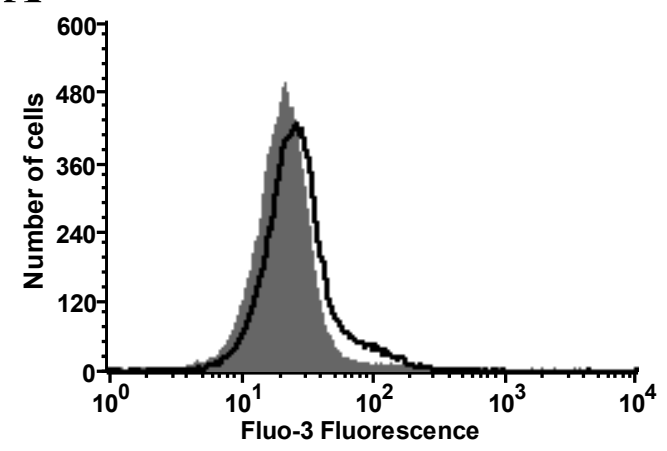

A
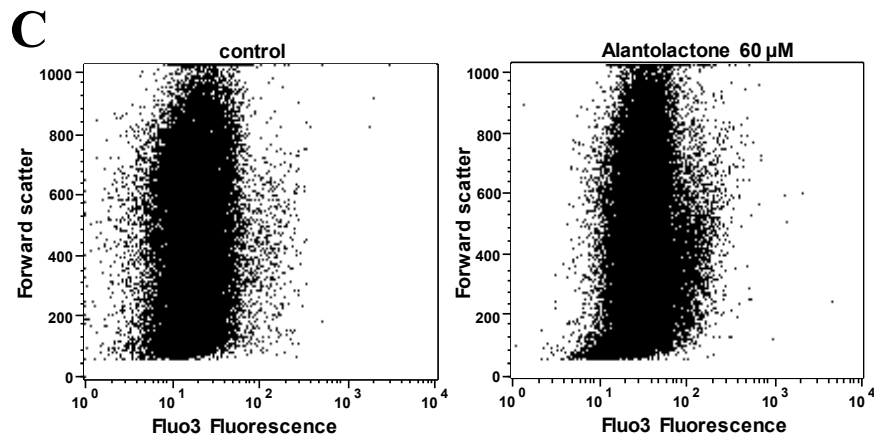

B

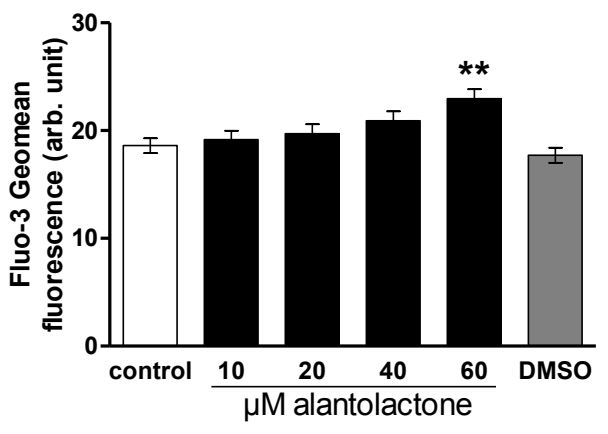

D

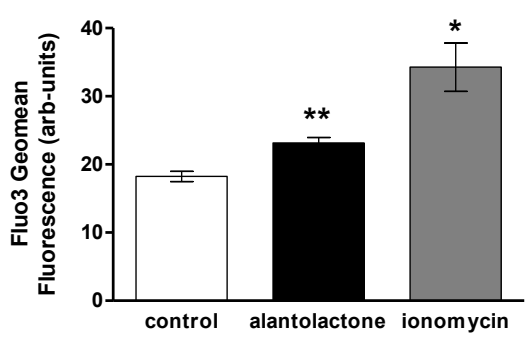


In order to test whether the alantolactone induced cell membrane scrambling required entry of extracellular $\mathrm{Ca}^{2+}$, erythrocytes were exposed for $48 \mathrm{~h}$ to $60 \mu \mathrm{M}$ alantolactone in the presence or nominal absence of extracellular $\mathrm{Ca}^{2+}$. As illustrated in Figure 4A, the effect of alantolactone on annexin-V-binding was not significantly modified by removal of extracellular $\mathrm{Ca}^{2+}$. Thus, the effect of alantolactone on annexin-V-binding did not depend on $\mathrm{Ca}^{2+}$ entry. To ascertain that the high calcium content $(5 \mathrm{mM})$ in the staining solution did not affect the results, the effect ionomycin was studied using the same protocol. As illustrated in Figure 4B, the effect of ionomycin on annexin-V-binding was completely abrogated by removal of extracellular $\mathrm{Ca}^{2+}$.

Figure 4. Effect of $\mathrm{Ca}^{2+}$ withdrawal on alantolactone- or ionomycin-induced phosphatidylserine exposure. (A) Arithmetic means \pm SEM $(n=10)$ of annexin-V-binding erythrocytes after a $48 \mathrm{~h}$ treatment with Ringer solution without (white bar) or with (black bars) $60 \mu \mathrm{M}$ alantolactone in the presence (left bars, $+\mathrm{Ca}^{2+}$ ) and absence (right bars, $\left.-\mathrm{Ca}^{2+}\right)$ of calcium. $* * *(p<0.001)$ indicates significant difference from the respective values in the absence of alantolactone (ANOVA); (B) Arithmetic means $\pm \operatorname{SEM}(n=4)$ of annexin-V-binding erythrocytes after a $1 \mathrm{~h}$ treatment with Ringer solution without (white bar) or with (black bars) $1 \mu \mathrm{M}$ ionomycin in the presence (left bars, $+\mathrm{Ca}^{2+}$ ) and absence (right bars, $\left.-\mathrm{Ca}^{2+}\right)$ of calcium. $* * *(p<0.001)$ indicates significant difference from the respective values in the absence of ionomycin (ANOVA).
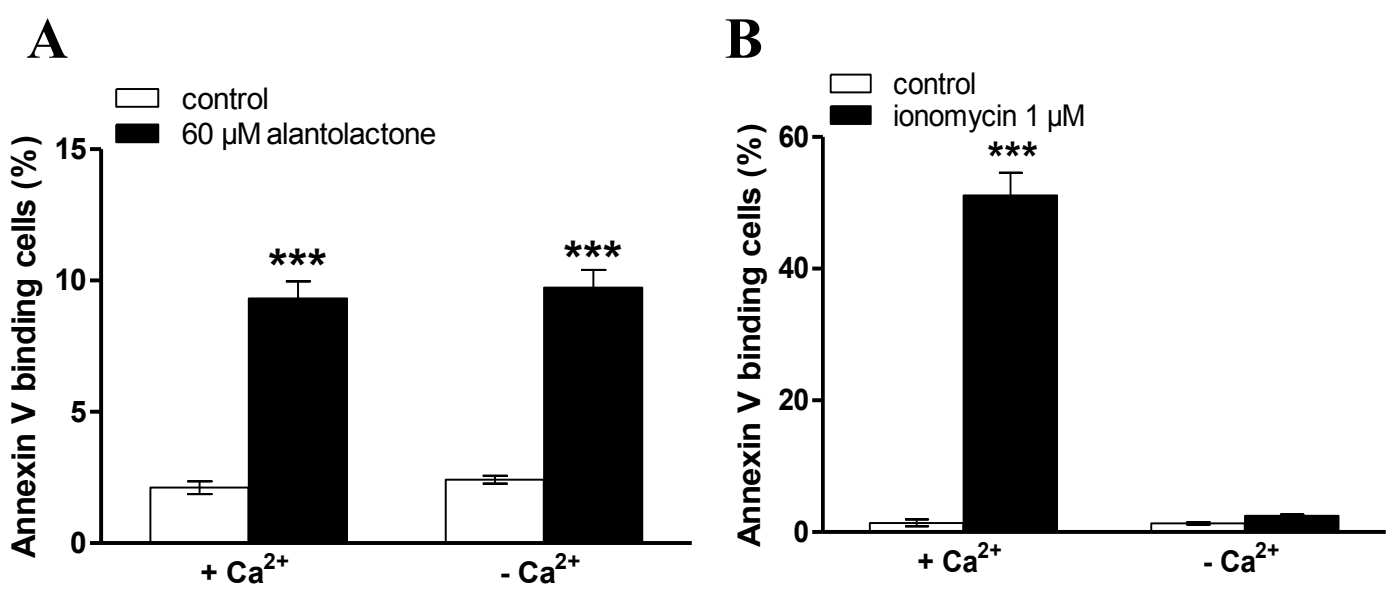

Mechanisms stimulating eryptosis without increase of $\left[\mathrm{Ca}^{2+}\right]_{i}$ include ceramide. Thus, additional experiments were performed in order to quantify the effect of alantolactone on the ceramide abundance at the erythrocyte surface. To this end the ceramide abundance was determined utilizing a fluorescent anti-ceramide antibody. As shown in Figure 5, a $48 \mathrm{~h}$ exposure of erythrocytes to $60 \mu \mathrm{M}$ alantolactone significantly increased the abundance of ceramide at the erythrocyte surface.

Eryptosis is further triggered by oxidative stress. Thus, DCFDA fluorescence was determined to estimate reactive oxygen species (ROS). As illustrated in Figure 6, a $48 \mathrm{~h}$ exposure to alantolactone (40 or $60 \mu \mathrm{M}$ ) was followed by a significant increase of DCFDA fluorescence pointing to induction of oxidative stress.

Additional experiments addressed the effect of alantolactone on flippase and scramblase activity. To this end, erythrocytes were exposed for $48 \mathrm{~h}$ to alantolactone $(60 \mu \mathrm{M})$ and the uptake of NBD-PS-(1-palmitoyl-2-[6-[(7-nitro-2-1,3-benzoxadiazol-4-yl)amino]-hexanoyl]-sn-glycero-3-phos-phoserine) 
determined as a measure of flippase activity and the uptake of NBD-PC (1-Oleoyl-2-[12-[(7-nitro-21,3-benzoxadiazol-4-yl)amino]dodecanoyl]-sn-Glycero-3-Phosphocholine) determined as a measure of scramblase activity. Within $60 \mathrm{~min}$ the NBD-PS uptake was significantly lower in alantolactone treated erythrocytes $(7.9 \% \pm 0.3 \%, n=4)$ than in untreated erythrocytes $(22.8 \% \pm 1.1 \%, n=4)$, whereas the NBD-PC uptake was significantly higher in alantolactone treated erythrocytes $(73.9 \% \pm 3.1 \%, n=4)$ than in untreated erythrocytes $(52.8 \% \pm 1.2 \%, n=4)$.

Figure 5. Effect of alantolactone on ceramide formation. (A) Original histogram of ceramide surface abundance of erythrocytes following exposure for $48 \mathrm{~h}$ to Ringer solution without (grey shadow) and with (black line) presence of $60 \mu \mathrm{M}$ alantolactone; (B) Arithmetic means $\pm \operatorname{SEM}(n=10)$ of ceramide abundance after a $48 \mathrm{~h}$ incubation in Ringer solution without (white bar) or with $60 \mu \mathrm{M}$ alantolactone (black bar). * $(p<0.05)$ indicates significant difference from the absence of alantolactone $(t$ test $)$; (C) Original dot plots of forward scatter vs ceramide dependent fluorescence of erythrocytes following exposure for $48 \mathrm{~h}$ to Ringer solution without (left) and with (right) presence of $60 \mu \mathrm{M}$ alantolactone.

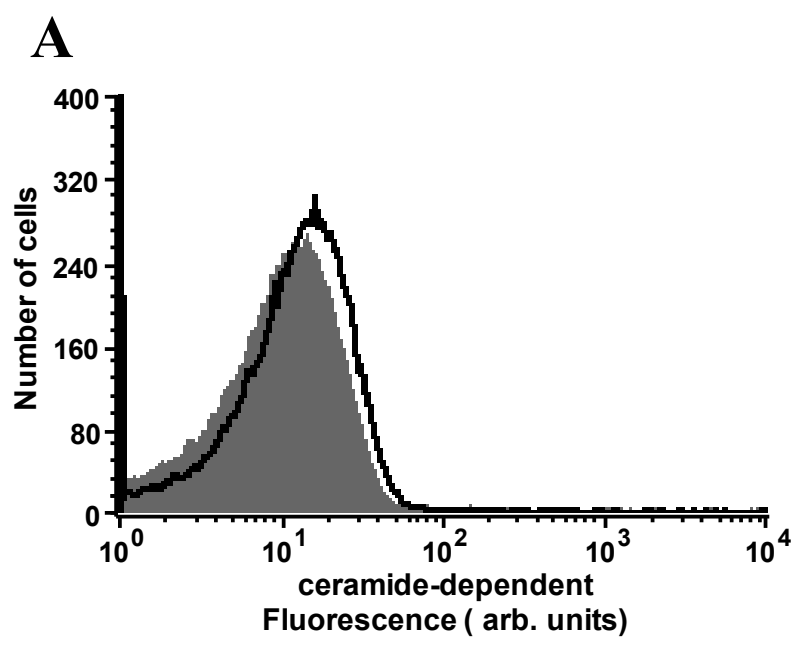

\section{B}
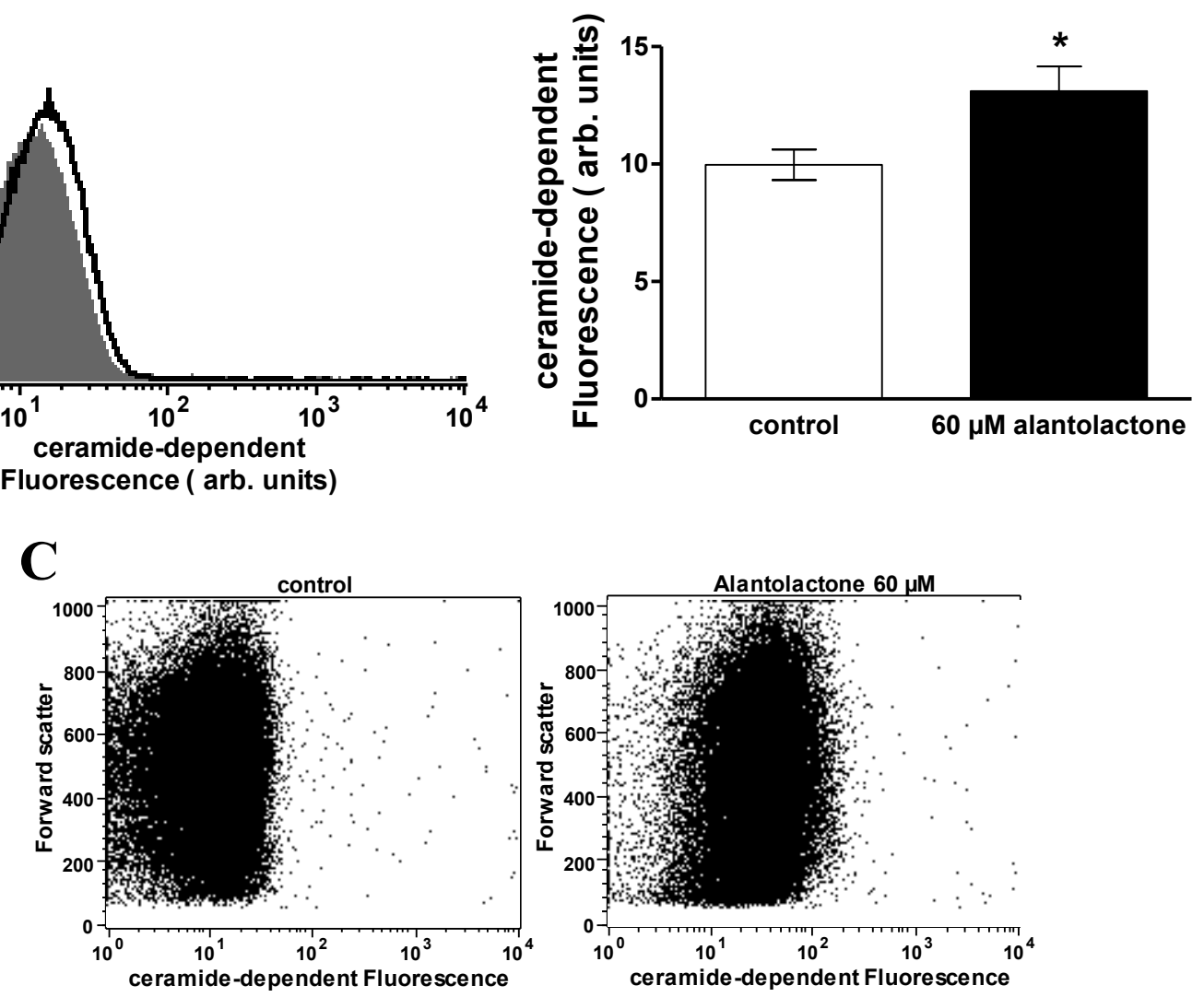
Figure 6. Effect of alantolactone on DCFDA fluorescence. (A) Original histogram of 2',7'-dichlorodihydrofluorescein diacetate (DCFDA) fluorescence following exposure for $48 \mathrm{~h}$ to Ringer solution without (grey area) and with (black line) presence of $60 \mu \mathrm{M}$ alantolactone; (B) Arithmetic means $\pm \operatorname{SEM}(n=10)$ of erythrocyte DCFDA-fluorescence following incubation for $48 \mathrm{~h}$ to Ringer solution without (white bar) or with (black bars) presence of alantolactone $(40-60 \mu \mathrm{M}) . * *(p<0.01), * * *(p<0.001)$ indicates significant difference from the absence of alantolactone (ANOVA); (C) Original dot plots of forward scatter $v s$. DCFDA fluorescence of erythrocytes following exposure for $48 \mathrm{~h}$ to Ringer solution without (left) and with (right) presence of $60 \mu \mathrm{M}$ alantolactone.

A

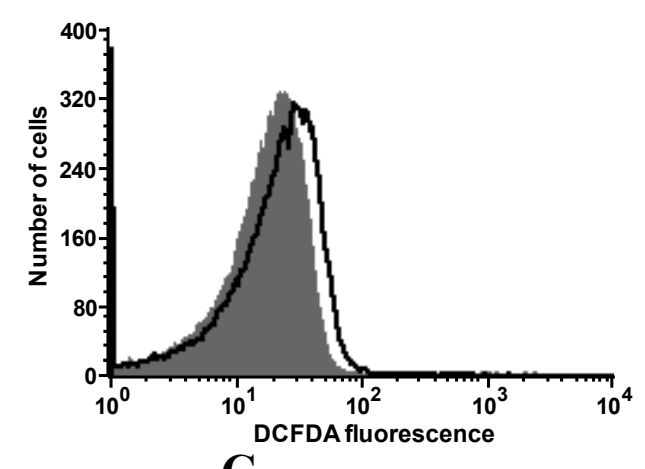

C
B
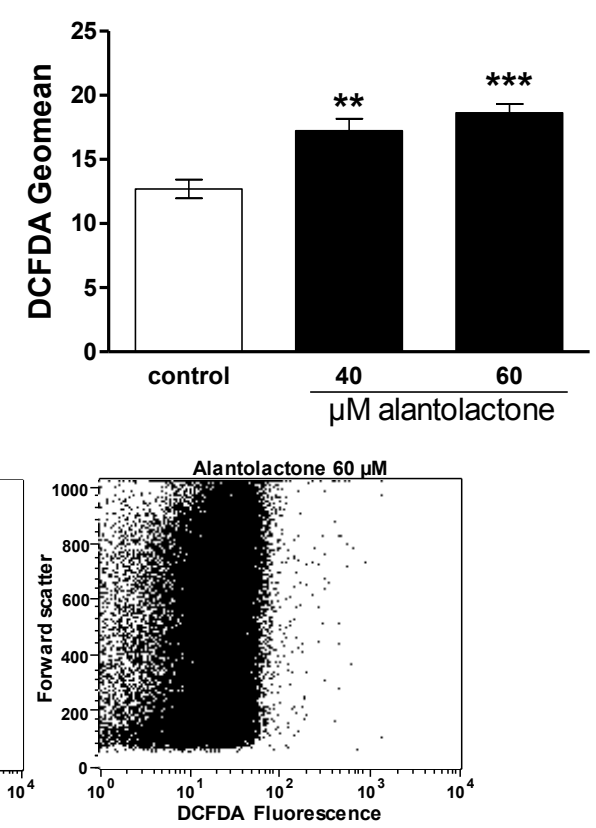

The present study reveals that alantolactone triggers eryptosis, the suicidal death of erythrocytes, i.e., of cells without mitochondria and without nuclei and thus unable to undergo mitochondrial triggering of cell death or modifying the expression of proteins involved in the machinery leading to cell death.

Apparently higher concentrations of alantolactone are required to appreciably increase $\left[\mathrm{Ca}^{2+}\right]_{i}$ than the alantolactone concentrations required for stimulation of phosphatidylserine translocation or induction of cell shrinkage. Moreover, the removal of extracellular $\mathrm{Ca}^{2+}$ did not appreciably modify alantolactone induced cell membrane scrambling. Thus, entry of extracellular $\mathrm{Ca}^{2+}$ cannot account for the stimulation of eryptosis by alantolactone. Instead, stimulation of eryptosis by alantolactone presumably involves ceramide formation and induction of oxidative stress. NBD-PS and NBD-PC uptake studies point to the modification of flippase and scramblase activities.

The cell shrinkage, which is presumably in part due to due to activation of $\mathrm{Ca}^{2+}$ sensitive $\mathrm{K}^{+}$ channels and subsequent cellular loss of $\mathrm{KCl}$ and water [13], is only mild and much less pronounced than the cell shrinkage induced by the $\mathrm{Ca}^{2+}$ ionophore ionomycin. Close inspection of the histogram in Figure 1 reveals that a small subpopulation of erythrocytes even rather swells. Possibly, alantolactone stimulated $\mathrm{Na}^{+}$entry, which may in some cells override $\mathrm{K}^{+}$exit. In contrast to its strong effect on 
eryptosis, alantolactone treatment tended to only slightly increase hemolysis, an effect not reaching statistical significance (Figure 2).

The cell shrinkage serves to counteract cell swelling and the phosphatidylserine exposure at the cell surface is an "eat me" signal leading to phagocytosis of eryptotic cells. The triggering of eryptosis thus counteracts hemolysis of defective erythrocytes. The hemolysis would otherwise be followed by release of hemoglobin, which may be filtered in renal glomeruli and subsequently precipitate in the acidic lumen of renal tubules [68]. The removal of eryptotic erythrocytes is an important host defence mechanism during infection with Plasmodia [69]. The intraerythrocytic parasite activates several ion channels in the host cell membrane including the $\mathrm{Ca}^{2+}$-permeable erythrocyte cation channels [70,71]. The subsequent $\mathrm{Ca}^{2+}$ entry triggers eryptosis with subsequent clearance of the infected erythrocytes from circulating blood [69,72]. Accordingly, genetic disorders sensitizing erythrocytes to eryptosis, such as sickle-cell trait, beta-thalassemia-trait, homozygous Hb-C and G6PD-deficiency [12,73-75], lead to accelerated eryptosis of infected erythrocytes thus counteracting parasitemia and a severe course of the disease [69]. Similarly, some clinical conditions fostering eryptosis, such as iron deficiency [72], and several eryptosis stimulating xenobiotics, such as lead [76], chlorpromazine [77] or NO synthase inhibitors [78] have been shown to favourably influence the clinical course of malaria. It remains to be tested, whether alantolactone influences the clinical course of malaria.

The in vivo clearance of eryptotic erythrocytes from circulating blood [12,79-82] may result in anemia, as soon as the rate of eryptosis with subsequent clearance from circulating blood exceeds the formation of new erythrocytes [12]. Moreover, phosphatidylserine exposing erythrocytes adhere to endothelial CXCL16/SR-PSO [83], stimulate blood clotting and thrombosis [84-86] and thus interfere with microcirculation $[83,84,87-90]$.

The alantolactone concentrations required for stimulation of eryptosis were similar to those effective in cancer cells [2-11]. In theory, enhanced eryptosis may thus limit the use of alantolactone in the treatment of tumors. It must be kept in mind that eryptosis is enhanced in malignancy [82], a complication presumably compounded by therapeutic use of eryptosis inducing substances.

\section{Experimental Section}

\subsection{Erythrocytes, Solutions and Chemicals}

Fresh Li-Heparin-anticoagulated blood samples were kindly provided by the blood bank of the University of Tübingen. The study is approved by the ethics committee of the University of Tübingen $(184 / 2003 \mathrm{~V})$. The blood was centrifuged at $120 \mathrm{rcf}$ for $20 \mathrm{~min}$ at room temperature and the platelets and leukocytes-containing supernatant was disposed. Erythrocytes were incubated in vitro at a hematocrit of $0.4 \%$ in Ringer solution containing (in $\mathrm{mM}$ ) $125 \mathrm{NaCl}, 5 \mathrm{KCl}, 1 \mathrm{MgSO}$, $32 \mathrm{~N}$-2-hydroxyethylpiperazine- $\mathrm{N}$-2-ethanesulfonic acid (HEPES), 5 glucose, $1 \mathrm{CaCl}_{2} ; \mathrm{pH} 7.4$ at $37{ }^{\circ} \mathrm{C}$ for $48 \mathrm{~h}$. Where indicated, erythrocytes were exposed to alantolactone (Sigma Aldrich, Schnelldorf, Germany) at the indicated concentrations, solved in $1 \mu \mathrm{L} / \mathrm{mL}$ DMSO. For comparison, the effect of $1 \mu \mathrm{L} \mathrm{DMSO} / \mathrm{mL}$ Ringer was tested. 


\subsection{Analysis of Annexin-V-Binding and Forward Scatter}

After incubation under the respective experimental condition, $150 \mu \mathrm{L}$ cell suspension was washed in Ringer solution containing $5 \mathrm{mM} \mathrm{CaCl}_{2}$ and then stained with Annexin-V-FITC (1:200 dilution; ImmunoTools, Friesoythe, Germany) in this solution at $37{ }^{\circ} \mathrm{C}$ for 20 min under protection from light. In the following, the forward scatter (FSC) of the cells was determined, and annexin-V fluorescence intensity was measured with an excitation wavelength of $488 \mathrm{~nm}$ and an emission wavelength of $530 \mathrm{~nm}$ on a FACS Calibur (BD, Heidelberg, Germany). The incubation with Annexin-V-FITC required presence of $5 \mathrm{mM} \mathrm{CaCl}_{2}$ even in experiments on the effect of a $48 \mathrm{~h}$ incubation with alantolactone in the absence of $\mathrm{Ca}^{2+}$. In order to test whether the short incubation with $5 \mathrm{mM} \mathrm{Ca}^{2+}$ could have biased the results, experiments were performed in erythrocytes treated with $\mathrm{Ca}^{2+}$ ionophore ionomycin. As indicated in Figure 4, a $20 \mathrm{~min}$ exposure to extracellular $\mathrm{Ca}^{2+}$ in the presence of $\mathrm{Ca}^{2+}$ ionophore ionomycin $(1 \mu \mathrm{M})$ was not sufficient to trigger significant annexin-V binding.

\subsection{Measurement of Intracellular $\mathrm{Ca}^{2+}$}

After incubation erythrocytes were washed in Ringer solution and then loaded with Fluo-3/AM (Biotium, Hayward, CA, USA) in Ringer solution containing $5 \mathrm{mM} \mathrm{CaCl}_{2}$ and $5 \mu \mathrm{M}$ Fluo-3/AM. The cells were incubated at $37^{\circ} \mathrm{C}$ for $30 \mathrm{~min}$ and washed twice in Ringer solution containing $5 \mathrm{mM} \mathrm{CaCl}_{2}$. The Fluo-3/AM-loaded erythrocytes were resuspended in $200 \mu \mathrm{L}$ Ringer. Then, $\mathrm{Ca}^{2+}$-dependent fluorescence intensity was measured with an excitation wavelength of $488 \mathrm{~nm}$ and an emission wavelength of $530 \mathrm{~nm}$ on a FACS Calibur.

\subsection{Determination of Ceramide Formation}

To determine ceramide abundance, a monoclonal antibody-based assay was used. After incubation, cells were stained for $1 \mathrm{~h}$ at $37^{\circ} \mathrm{C}$ with $1 \mu \mathrm{g} / \mathrm{mL}$ anti-ceramide antibody (clone MID 15B4; Alexis, Grünberg, Germany) in phosphate-buffered saline (PBS) containing $0.1 \%$ bovine serum albumin (BSA) at a dilution of 1:10. After two washing steps with PBS-BSA, cells were stained for $30 \mathrm{~min}$ with polyclonal fluorescein- isothiocyanate (FITC)-conjugated goat anti-mouse IgG and IgM specific antibody (Pharmingen, Hamburg, Germany) diluted 1:50 in PBS-BSA. Unbound secondary antibody was removed by repeated washing with PBS-BSA. Samples were then analyzed by flow cytometric analysis at an excitation wavelength of $488 \mathrm{~nm}$ and an emission wavelength of $530 \mathrm{~nm}$.

\subsection{Determination of Reactive Oxygen Species (ROS)}

ROS production was determined utilizing 2',7'-dichlorodihydrofluorescein diacetate (DCFDA). Briefly, the cells were suspended in FACS buffer and the fluorescence was analysed with flow cytometry (FACS-Calibur from Becton Dickinson; Heidelberg, Germany). DCFDA fluorescence intensity was measured in FL-1 with an excitation wavelength of $488 \mathrm{~nm}$ and an emission wavelength of $530 \mathrm{~nm}$. 


\subsection{Measurement of Phospholipid Translocation}

Phospholipid translocation was measured according to methods describes previously [91]. Cells were incubated with $60 \mu \mathrm{M}$ alantolactone for $48 \mathrm{~h}$ and then loaded with $2 \mu \mathrm{M}$ of NBD-PS 1-palmitoyl2-[6-[(7-nitro-2-1,3-benzoxadiazol-4-yl)amino]hexanoyl]-sn-glycero-3-phosphoserine as a measure of flippase activity or NBD-PC 1-Oleoyl-2-[12-[(7-nitro-2-1,3-benzoxadiazol-4-yl)amino]dodecanoyl]-snGlycero-3-Phosphocholine as a measure of scramblase activity. Both are from Avanti Polar Lipids (Alabaster, AL, USA). After 60 min aliquots were obtained and resuspended in ice cold PBS for $10 \mathrm{~min}$ in the presence or absence of $1 \% \mathrm{BSA}$. The amount of translocated probe was determined by dividing the mean fluorescence intensity of the sample after BSA extraction (internalized probe) by that in absence of BSA (total probe). Analysis was done using FACS-Calibur from Becton Dickinson; Heidelberg, Germany.

\subsection{Statistics}

Data are expressed as arithmetic means \pm SEM. As indicated in the figure legends, statistical analysis was made using ANOVA with Tukey's test as post-test and $t$ test as appropriate. $n$ denotes the number of different erythrocyte specimens studied. Since different erythrocyte specimens used in distinct experiments are differently susceptible to triggers of eryptosis, the same erythrocyte specimens have been used for control and experimental conditions.

\section{Conclusions}

Exposure of human erythrocytes to alantolactone is followed by stimulation of eryptosis, characterized by erythrocyte shrinkage and phosphatidylserine translocation to the erythrocyte surface. Signaling involved includes increase of $\left[\mathrm{Ca}^{2+}\right]$, ceramide formation and induction of oxidative stress.

\section{Acknowledgments}

The authors acknowledge the meticulous preparation of the manuscript by Tanja Loch. The study was supported by the Deutsche Forschungsgemeinschaft and the Open Access Publishing Fund of Tuebingen University.

\section{Author Contributions}

S.C., K.A., J.E. and C.F. performed experiments and evaluated data. F.L. drafted the manuscript. All authors approved the finalized version of the manuscript.

\section{Conflicts of Interest}

The authors declare no conflict of interest. 


\section{References}

1. Rasul, A.; Khan, M.; Ali, M.; Li, J.; Li, X. Targeting apoptosis pathways in cancer with alantolactone and isoalantolactone. Sci. World J. 2013, $2013,248532$.

2. Dirsch, V.M.; Stuppner, H.; Vollmar, A.M. Cytotoxic sesquiterpene lactones mediate their death-inducing effect in leukemia T cells by triggering apoptosis. Planta Med. 2001, 67, 557-559.

3. Khan, M.; Li, T.; Ahmad Khan, M.K.; Rasul, A.; Nawaz, F.; Sun, M.; Zheng, Y.; Ma, T. Alantolactone induces apoptosis in HepG2 cells through GSH depletion, inhibition of STAT3 activation, and mitochondrial dysfunction. Biomed. Res. Int. 2013, 2013, 719858.

4. Khan, M.; Yi, F.; Rasul, A.; Li, T.; Wang, N.; Gao, H.; Gao, R.; Ma, T. Alantolactone induces apoptosis in glioblastoma cells via GSH depletion, ROS generation, and mitochondrial dysfunction. IUBMB Life 2012, 64, 783-794.

5. Lawrence, N.J.; McGown, A.T.; Nduka, J.; Hadfield, J.A.; Pritchard, R.G. Cytotoxic Michael-type amine adducts of alpha-methylene lactones alantolactone and isoalantolactone. Bioorg. Med. Chem. Lett. 2001, 11, 429-431.

6. Lei, J.C.; Yu, J.Q.; Yin, Y.; Liu, Y.W.; Zou, G.L. Alantolactone induces activation of apoptosis in human hepatoma cells. Food Chem. Toxicol. 2012, 50, 3313-3319.

7. Mi, X.G.; Song, Z.B.; Wu, P.; Zhang, Y.W.; Sun, L.G.; Bao, Y.L.; Zhang, Y.; Zheng, L.H.; Sun, Y.; Yu, C.L.; et al. Alantolactone induces cell apoptosis partially through down-regulation of testes-specific protease 50 expression. Toxicol. Lett. 2014, 224, 349-355.

8. Pal, H.C.; Sehar, I.; Bhushan, S.; Gupta, B.D.; Saxena, A.K. Activation of caspases and poly (ADP-ribose) polymerase cleavage to induce apoptosis in leukemia HL-60 cells by Inula racemosa. Toxicol. Vitr. 2010, 24, 1599-1609.

9. Wei, W.; Huang, H.; Zhao, S.; Liu, W.; Liu, C.X.; Chen, L.; Li, J.M.; Wu, Y.L.; Yan, H. Alantolactone induces apoptosis in chronic myelogenous leukemia sensitive or resistant to imatinib through NF-kappaB inhibition and Bcr/Abl protein deletion. Apoptosis 2013, 18, 1060-1070.

10. Yang, C.; Yang, J.; Sun, M.; Yan, J.; Meng, X.; Ma, T. Alantolactone inhibits growth of K562/adriamycin cells by downregulating $\mathrm{Bcr} / \mathrm{Abl}$ and $\mathrm{P}$-glycoprotein expression. IUBMB Life 2013, 65, 435-444.

11. Zhang, Y.; Bao, Y.L.; Wu, Y.; Yu, C.L.; Huang, Y.X.; Sun, Y.; Zheng, L.H.; Li, Y.X. Alantolactone induces apoptosis in RKO cells through the generation of reactive oxygen species and the mitochondrial pathway. Mol. Med. Rep. 2013, 8, 967-972.

12. Lang, E.; Qadri, S.M.; Lang, F. Killing me softly-Suicidal erythrocyte death. Int. J. Biochem. Cell Biol. 2012, 44, 1236-1243.

13. Lang, P.A.; Kaiser, S.; Myssina, S.; Wieder, T.; Lang, F.; Huber, S.M. Role of $\mathrm{Ca}^{2+}$-activated K channels in human erythrocyte apoptosis. Am. J. Physiol. Cell Physiol. 2003, 285, C1553-C1560.

14. Abed, M.; Towhid, S.T.; Mia, S.; Pakladok, T.; Alesutan, I.; Borst, O.; Gawaz, M.; Gulbins, E.; Lang, F. Sphingomyelinase-induced adhesion of eryptotic erythrocytes to endothelial cells. Am. J. Physiol. Cell Physiol. 2012, 303, C991-C999.

15. Lang, F.; Abed, M.; Lang, E.; Foller, M. Oxidative stress and suicidal erythrocyte death. Antioxid. Redox Signal. 2014, 21, 138-153. 
16. Bhavsar, S.K.; Bobbala, D.; Xuan, N.T.; Foller, M.; Lang, F. Stimulation of suicidal erythrocyte death by alpha-lipoic acid. Cell. Physiol. Biochem. 2010, 26, 859-868.

17. Foller, M.; Feil, S.; Ghoreschi, K.; Koka, S.; Gerling, A.; Thunemann, M.; Hofmann, F.; Schuler, B.; Vogel, J.; Pichler, B.; et al. Anemia and splenomegaly in cGKI-deficient mice. Proc. Natl. Acad. Sci. USA 2008, 105, 6771-6776.

18. Foller, M.; Mahmud, H.; Gu, S.; Wang, K.; Floride, E.; Kucherenko, Y.; Luik, S.; Laufer, S.; Lang, F. Participation of leukotriene $\mathrm{C}(4)$ in the regulation of suicidal erythrocyte death. J. Physiol. Pharmacol. 2009, 60, 135-143.

19. Lau, I.P.; Chen, H.; Wang, J.; Ong, H.C.; Leung, K.C.; Ho, H.P.; Kong, S.K. In vitro effect of CTAB- and PEG-coated gold nanorods on the induction of eryptosis/erythroptosis in human erythrocytes. Nanotoxicology 2012, 6, 847-856.

20. Maellaro, E.; Leoncini, S.; Moretti, D.; Del Bello, B.; Tanganelli, I.; de Felice, C.; Ciccoli, L. Erythrocyte caspase-3 activation and oxidative imbalance in erythrocytes and in plasma of type 2 diabetic patients. Acta Diabetol. 2013, 50, 489-495.

21. Foller, M.; Sopjani, M.; Koka, S.; Gu, S.; Mahmud, H.; Wang, K.; Floride, E.; Schleicher, E.; Schulz, E.; Munzel, T.; et al. Regulation of erythrocyte survival by AMP-activated protein kinase. FASEB J. 2009, 23, 1072-1080.

22. Zelenak, C.; Foller, M.; Velic, A.; Krug, K.; Qadri, S.M.; Viollet, B.; Lang, F.; Macek, B. Proteome analysis of erythrocytes lacking AMP-activated protein kinase reveals a role of PAK2 kinase in eryptosis. J. Proteome Res. 2011, 10, 1690-1697.

23. Lupescu, A.; Jilani, K.; Zelenak, C.; Zbidah, M.; Qadri, S.M.; Lang, F. Hexavalent chromium-induced erythrocyte membrane phospholipid asymmetry. Biometals 2012, 25, 309-318.

24. Shaik, N.; Lupescu, A.; Lang, F. Sunitinib-sensitive suicidal erythrocyte death. Cell. Physiol. Biochem. 2012, 30, 512-522.

25. Kucherenko, Y.; Zelenak, C.; Eberhard, M.; Qadri, S.M.; Lang, F. Effect of casein kinase 1alpha activator pyrvinium pamoate on erythrocyte ion channels. Cell. Physiol. Biochem. 2012, 30, 407-417.

26. Zelenak, C.; Eberhard, M.; Jilani, K.; Qadri, S.M.; Macek, B.; Lang, F. Protein kinase CK1alpha regulates erythrocyte survival. Cell. Physiol. Biochem. 2012, 29, 171-180.

27. Bhavsar, S.K.; Gu, S.; Bobbala, D.; Lang, F. Janus kinase 3 is expressed in erythrocytes, phosphorylated upon energy depletion and involved in the regulation of suicidal erythrocyte death. Cell. Physiol. Biochem. 2011, 27, 547-556.

28. Klarl, B.A.; Lang, P.A.; Kempe, D.S.; Niemoeller, O.M.; Akel, A.; Sobiesiak, M.; Eisele, K.; Podolski, M.; Huber, S.M.; Wieder, T.; et al. Protein kinase C mediates erythrocyte "programmed cell death" following glucose depletion. Am. J. Physiol. Cell Physiol. 2006, 290, C244-C253.

29. Gatidis, S.; Zelenak, C.; Fajol, A.; Lang, E.; Jilani, K.; Michael, D.; Qadri, S.M.; Lang, F. p38 MAPK activation and function following osmotic shock of erythrocytes. Cell. Physiol. Biochem. 2011, 28, 1279-1286.

30. Abed, M.; Feger, M.; Alzoubi, K.; Pakladok, T.; Frauenfeld, L.; Geiger, C.; Towhid, S.T.; Lang, F. Sensitization of erythrocytes to suicidal erythrocyte death following water deprivation. Kidney Blood Press. Res. 2013, 37, 567-578. 
31. Abed, M.; Herrmann, T.; Alzoubi, K.; Pakladok, T.; Lang, F. Tannic Acid induced suicidal erythrocyte death. Cell. Physiol. Biochem. 2013, 32, 1106-1116.

32. Ahmed, M.S.; Langer, H.; Abed, M.; Voelkl, J.; Lang, F. The uremic toxin acrolein promotes suicidal erythrocyte death. Kidney Blood Press. Res. 2013, 37, 158-167.

33. Aithal, K.B.; Kumar, S.; Rao, B.N.; Udupa, N.; Rao, S.B. Tumor growth inhibitory effect of juglone and its radiation sensitizing potential: In vivo and in vitro studies. Integr. Cancer Ther. 2012, 11, 68-80.

34. Alzoubi, K.; Honisch, S.; Abed, M.; Lang, F. Triggering of suicidal erythrocyte death by penta- $O$-galloyl- $\beta$-D-glucose. Toxins (Basel) 2014, 6, 54-65.

35. Arnold, M.; Bissinger, R.; Lang, F. Mitoxantrone-Induced suicidal erythrocyte death. Cell. Physiol. Biochem. 2014, 34, 1756-1767.

36. Bissinger, R.; Lupescu, A.; Zelenak, C.; Jilani, K.; Lang, F. Stimulation of eryptosis by cryptotanshinone. Cell. Physiol. Biochem. 2014, 34, 432-442.

37. Bottger, E.; Multhoff, G.; Kun, J.F.; Esen, M. Plasmodium falciparum-infected erythrocytes induce granzyme B by NK cells through expression of host-Hsp70. PLoS One 2012, 7, e33774.

38. Chae, J.I.; Cho, J.H.; Kim, D.J.; Lee, K.A.; Cho, M.K.; Nam, H.S.; Woo, K.M.; Lee, S.H.; Shim, J.H. Phosphoinositol 3-kinase, a novel target molecule for the inhibitory effects of juglone on TPA-induced cell transformation. Int. J. Mol. Med. 2012, 30, 8-14.

39. Firat, U.; Kaya, S.; Cim, A.; Buyukbayram, H.; Gokalp, O.; Dal, M.S.; Tamer, M.N. Increased caspase-3 immunoreactivity of erythrocytes in STZ diabetic rats. Exp. Diabetes Res. 2012, $2012,316384$.

40. Gao, M.; Cheung, K.L.; Lau, I.P.; Yu, W.S.; Fung, K.P.; Yu, B.; Loo, J.F.; Kong, S.K. Polyphyllin D induces apoptosis in human erythrocytes through $\mathrm{Ca}^{2+}$ rise and membrane permeabilization. Arch. Toxicol. 2012, 86, 741-752.

41. Ghashghaeinia, M.; Cluitmans, J.C.; Akel, A.; Dreischer, P.; Toulany, M.; Koberle, M.; Skabytska, Y.; Saki, M.; Biedermann, T.; Duszenko, M.; et al. The impact of erythrocyte age on eryptosis. Br. J. Haematol. 2012, 157, 606-614.

42. Ghashghaeinia, M.; Cluitmans, J.C.; Toulany, M.; Saki, M.; Koberle, M.; Lang, E.; Dreischer, P.; Biedermann, T.; Duszenko, M.; Lang, F.; et al. Age sensitivity of NFkappaB abundance and programmed cell death in erythrocytes induced by NFkappaB inhibitors. Cell. Physiol. Biochem. 2013, 32, 801-813.

43. Jacobi, J.; Lang, E.; Bissinger, R.; Frauenfeld, L.; Modicano, P.; Faggio, C.; Abed, M.; Lang, F. Stimulation of erythrocyte cell membrane scrambling by mitotane. Cell. Physiol. Biochem. 2014, $33,1516-1526$.

44. Jilani, K.; Enkel, S.; Bissinger, R.; Almilaji, A.; Abed, M.; Lang, F. Fluoxetine induced suicidal erythrocyte death. Toxins (Basel) 2013, 5, 1230-1243.

45. Jilani, K.; Lang, F. Carmustine-induced phosphatidylserine translocation in the erythrocyte membrane. Toxins (Basel) 2013, 5, 703-716.

46. Jilani, K.; Lupescu, A.; Zbidah, M.; Abed, M.; Shaik, N.; Lang, F. Enhanced apoptotic death of erythrocytes induced by the mycotoxin ochratoxin A. Kidney Blood Press. Res. 2012, 36, 107-118.

47. Jilani, K.; Qadri, S.M.; Lang, F. Geldanamycin-induced phosphatidylserine translocation in the erythrocyte membrane. Cell. Physiol. Biochem. 2013, 32, 1600-1609. 
48. Kucherenko, Y.V.; Lang, F. Inhibitory effect of furosemide on non-selective voltage-independent cation channels in human erythrocytes. Cell. Physiol. Biochem. 2012, 30, 863-875.

49. Lang, E.; Qadri, S.M.; Jilani, K.; Zelenak, C.; Lupescu, A.; Schleicher, E.; Lang, F. Carbon monoxide-sensitive apoptotic death of erythrocytes. Basic Clin. Pharmacol. Toxicol. 2012, 111, $348-355$.

50. Lu, J.J.; Bao, J.L.; Wu, G.S.; Xu, W.S.; Huang, M.Q.; Chen, X.P.; Wang, Y.T. Quinones derived from plant secondary metabolites as anti-cancer agents. Anticancer Agents Med. Chem. 2013, 13, 456-463.

51. Lupescu, A.; Bissinger, R.; Herrmann, T.; Oswald, G.; Jilani, K.; Lang, F. Induction of suicidal erythrocyte death by novobiocin. Cell. Physiol. Biochem. 2014, 33, 670-680.

52. Lupescu, A.; Bissinger, R.; Jilani, K.; Lang, F. Triggering of suicidal erythrocyte death by celecoxib. Toxins (Basel) 2013, 5, 1543-1554.

53. Lupescu, A.; Bissinger, R.; Warsi, J.; Jilani, K.; Lang, F. Stimulation of erythrocyte cell membrane scrambling by gedunin. Cell. Physiol. Biochem. 2014, 33, 1838-1848.

54. Lupescu, A.; Jilani, K.; Zbidah, M.; Lang, F. Patulin-induced suicidal erythrocyte death. Cell. Physiol. Biochem. 2013, 32, 291-299.

55. Paulsen, M.T.; Ljungman, M. The natural toxin juglone causes degradation of p53 and induces rapid H2AX phosphorylation and cell death in human fibroblasts. Toxicol. Appl. Pharmacol. 2005, 209, 1-9.

56. Polak-Jonkisz, D.; Purzyc, L. Ca influx versus efflux during eryptosis in uremic erythrocytes. Blood Purif. 2012, 34, 209-210.

57. Qian, E.W.; Ge, D.T.; Kong, S.K. Salidroside protects human erythrocytes against hydrogen peroxide-induced apoptosis. J. Nat. Prod. 2012, 75, 531-537.

58. Shaik, N.; Zbidah, M.; Lang, F. Inhibition of $\mathrm{Ca}^{2+}$ entry and suicidal erythrocyte death by naringin. Cell. Physiol. Biochem. 2012, 30, 678-686.

59. Tesoriere, L.; Attanzio, A.; Allegra, M.; Cilla, A.; Gentile, C.; Livrea, M.A. Oxysterol mixture in hypercholesterolemia-relevant proportion causes oxidative stress-dependent eryptosis. Cell. Physiol. Biochem. 2014, 34, 1075-1089.

60. Vota, D.M.; Maltaneri, R.E.; Wenker, S.D.; Nesse, A.B.; Vittori, D.C. Differential erythropoietin action upon cells induced to eryptosis by different agents. Cell. Biochem. Biophys. 2013, 65, $145-157$.

61. Weiss, E.; Cytlak, U.M.; Rees, D.C.; Osei, A.; Gibson, J.S. Deoxygenation-induced and $\mathrm{Ca}^{2+}$ dependent phosphatidylserine externalisation in red blood cells from normal individuals and sickle cell patients. Cell Calcium 2012, 51, 51-56.

62. Xu, H.; Yu, X.; Qu, S.; Sui, D. Juglone, isolated from Juglans mandshurica Maxim, induces apoptosis via down-regulation of AR expression in human prostate cancer LNCaP cells. Bioorg. Med. Chem. Lett. 2013, 23, 3631-3634.

63. Zbidah, M.; Lupescu, A.; Jilani, K.; Lang, F. Stimulation of suicidal erythrocyte death by fumagillin. Basic Clin. Pharmacol. Toxicol. 2013, 112, 346-351.

64. Zelenak, C.; Pasham, V.; Jilani, K.; Tripodi, P.M.; Rosaclerio, L.; Pathare, G.; Lupescu, A.; Faggio, C.; Qadri, S.M.; Lang, F. Tanshinone IIA stimulates erythrocyte phosphatidylserine exposure. Cell. Physiol. Biochem. 2012, 30, 282-294. 
65. Zhang, R.; Xiang, Y.; Ran, Q.; Deng, X.; Xiao, Y.; Xiang, L.; Li, Z. Involvement of calcium, reactive oxygen species, and ATP in hexavalent chromium-induced damage in red blood cells. Cell. Physiol. Biochem. 2014, 34, 1780-1791.

66. Voelkl, J.; Alzoubi, K.; Mamar, A.K.; Ahmed, M.S.; Abed, M.; Lang, F. Stimulation of suicidal erythrocyte death by increased extracellular phosphate concentrations. Kidney Blood Press. Res. 2013, 38, 42-51.

67. Lang, E.; Gatidis, S.; Freise, N.F.; Bock, H.; Kubitz, R.; Lauermann, C.; Orth, H.M.; Klindt, C.; Schuier, M.; Keitel, V.; et al. Conjugated bilirubin triggers anemia by inducing erythrocyte death. Hepatology 2014, doi:10.1002/hep. 27338.

68. Harrison, H.E.; Bunting, H.; Ordway, N.K.; Albrink, W.S. The pathogenesis of the renal injury produced in the dog by hemoglobin or methemoglobin. J. Exp. Med. 1947, 86, 339-356.

69. Foller, M.; Bobbala, D.; Koka, S.; Huber, S.M.; Gulbins, E.; Lang, F. Suicide for survival—Death of infected erythrocytes as a host mechanism to survive malaria. Cell. Physiol. Biochem. 2009, 24, 133-140.

70. Duranton, C.; Huber, S.; Tanneur, V.; Lang, K.; Brand, V.; Sandu, C.; Lang, F. Electrophysiological properties of the Plasmodium Falciparum-induced cation conductance of human erythrocytes. Cell. Physiol. Biochem. 2003, 13, 189-198.

71. Kirk, K. Membrane transport in the malaria-infected erythrocyte. Physiol. Rev. 2001, 81, 495-537.

72. Koka, S.; Foller, M.; Lamprecht, G.; Boini, K.M.; Lang, C.; Huber, S.M.; Lang, F. Iron deficiency influences the course of malaria in Plasmodium berghei infected mice. Biochem. Biophys. Res. Commun. 2007, 357, 608-614.

73. Ayi, K.; Giribaldi, G.; Skorokhod, A.; Schwarzer, E.; Prendergast, P.T.; Arese, P. 16alpha-bromoepiandrosterone, an antimalarial analogue of the hormone dehydroepiandrosterone, enhances phagocytosis of ring stage parasitized erythrocytes: A novel mechanism for antimalarial activity. Antimicrob. Agents Chemother. 2002, 46, 3180-3184.

74. Ayi, K.; Turrini, F.; Piga, A.; Arese, P. Enhanced phagocytosis of ring-parasitized mutant erythrocytes: A common mechanism that may explain protection against falciparum malaria in sickle trait and beta-thalassemia trait. Blood 2004, 104, 3364-3371.

75. Cappadoro, M.; Giribaldi, G.; O’Brien, E.; Turrini, F.; Mannu, F.; Ulliers, D.; Simula, G.; Luzzatto, L.; Arese, P. Early phagocytosis of glucose-6-phosphate dehydrogenase (G6PD)-deficient erythrocytes parasitized by Plasmodium falciparum may explain malaria protection in G6PD deficiency. Blood 1998, 92, 2527-2534.

76. Koka, S.; Huber, S.M.; Boini, K.M.; Lang, C.; Foller, M.; Lang, F. Lead decreases parasitemia and enhances survival of Plasmodium berghei-infected mice. Biochem. Biophys. Res. Commun. 2007, 363, 484-489.

77. Koka, S.; Lang, C.; Boini, K.M.; Bobbala, D.; Huber, S.M.; Lang, F. Influence of chlorpromazine on eryptosis, parasitemia and survival of Plasmodium berghe infected mice. Cell. Physiol. Biochem. 2008, 22, 261-268.

78. Koka, S.; Lang, C.; Niemoeller, O.M.; Boini, K.M.; Nicolay, J.P.; Huber, S.M.; Lang, F. Influence of NO synthase inhibitor L-NAME on parasitemia and survival of Plasmodium berghei infected mice. Cell. Physiol. Biochem. 2008, 21, 481-488. 
79. Dasgupta, S.K.; Abdel-Monem, H.; Guchhait, P.; Nagata, S.; Thiagarajan, P. Role of lactadherin in the clearance of phosphatidylserine-expressing red blood cells. Transfusion 2008, 48, 2370-2376.

80. Foller, M.; Biswas, R.; Mahmud, H.; Akel, A.; Shumilina, E.; Wieder, T.; Goetz, F.; Lang, F. Effect of peptidoglycans on erythrocyte survival. Int. J. Med. Microbiol. 2009, 299, 75-85.

81. Khandelwal, S.; Saxena, R.K. A role of phosphatidylserine externalization in clearance of erythrocytes exposed to stress but not in eliminating aging populations of erythrocyte in mice. Exp. Gerontol. 2008, 43, 764-770.

82. Qadri, S.M.; Mahmud, H.; Lang, E.; Gu, S.; Bobbala, D.; Zelenak, C.; Jilani, K.; Siegfried, A.; Foller, M.; Lang, F. Enhanced suicidal erythrocyte death in mice carrying a loss-of-function mutation of the adenomatous polyposis coli gene. J. Cell. Mol. Med. 2012, 16, 1085-1093.

83. Borst, O.; Abed, M.; Alesutan, I.; Towhid, S.T.; Qadri, S.M.; Foller, M.; Gawaz, M.; Lang, F. Dynamic adhesion of eryptotic erythrocytes to endothelial cells via CXCL16/SR-PSOX. Am. J. Physiol. Cell Physiol. 2012, 302, C644-C651.

84. Andrews, D.A.; Low, P.S. Role of red blood cells in thrombosis. Curr. Opin. Hematol. 1999, 6, 76-82.

85. Chung, S.M.; Bae, O.N.; Lim, K.M.; Noh, J.Y.; Lee, M.Y.; Jung, Y.S.; Chung, J.H. Lysophosphatidic acid induces thrombogenic activity through phosphatidylserine exposure and procoagulant microvesicle generation in human erythrocytes. Arterioscler. Thromb. Vasc. Biol. 2007, 27, 414-421.

86. Zwaal, R.F.; Comfurius, P.; Bevers, E.M. Surface exposure of phosphatidylserine in pathological cells. Cell. Mol. Life Sci. 2005, 62, 971-988.

87. Closse, C.; Dachary-Prigent, J.; Boisseau, M.R. Phosphatidylserine-related adhesion of human erythrocytes to vascular endothelium. Br. J. Haematol. 1999, 107, 300-302.

88. Gallagher, P.G.; Chang, S.H.; Rettig, M.P.; Neely, J.E.; Hillery, C.A.; Smith, B.D.; Low, P.S. Altered erythrocyte endothelial adherence and membrane phospholipid asymmetry in hereditary hydrocytosis. Blood 2003, 101, 4625-4627.

89. Pandolfi, A.; Di Pietro, N.; Sirolli, V.; Giardinelli, A.; Di Silvestre, S.; Amoroso, L.; Di Tomo, P.; Capani, F.; Consoli, A.; Bonomini, M. Mechanisms of uremic erythrocyte-induced adhesion of human monocytes to cultured endothelial cells. J. Cell. Physiol. 2007, 213, 699-709.

90. Wood, B.L.; Gibson, D.F.; Tait, J.F. Increased erythrocyte phosphatidylserine exposure in sickle cell disease: Flow-cytometric measurement and clinical associations. Blood 1996, 88, 1873-1880.

91. Hilarius, P.M.; Ebbing, I.G.; Dekkers, D.W.; Lagerberg, J.W.; de Korte, D.; Verhoeven, A.J. Generation of singlet oxygen induces phospholipid scrambling in human erythrocytes. Biochemistry 2004, 43, 4012-4019.

(C) 2014 by the authors; licensee MDPI, Basel, Switzerland. This article is an open access article distributed under the terms and conditions of the Creative Commons Attribution license (http://creativecommons.org/licenses/by/4.0/). 